\title{
Preface to the special issue "Tectonics and depositional infilling of western Pacific marginal sea"
}

\author{
Xinong $\mathrm{Xie}^{1} \cdot$ Chi-Yue Huang ${ }^{2} \cdot$ Lei Shao ${ }^{2}$
}

Published online: 9 May 2019

(c) Springer Nature B.V. 2019

The South China Sea (SCS) is the largest marginal sea in the western Pacific region. Its evolutionary history, as one of the typical marginal sea basin, is neither as old as the Atlantic continental margin, nor as young as the Red Sea rifting. Because of its unique tectonic background and rich geological and geophysical data collected there, the SCS has become a natural laboratory to study plate interaction, continental marginal evolution, marginal sea dynamics mechanism and resource potentials in the western Pacific region. An 8-year key research program of the "South China Sea Deep" supported by the National Science Foundation of China, started in 2011, has included systematic studies on three aspects: deep-sea basin evolution, deep-sea deposition and biogeochemical processes. This special issue features at the key research result of "depositional infillings and basin evolution during the seafloor spreading of the SCS", and systematically summarizes the findings on tectonic evolution and depositional filling of the continental margin and ocean basin in the SCS.

This special issue includes eight papers, which are organized in three groups: (1) the relationship between the deep structure of lithosphere and the stratigraphic patterns; (2) tectonics and associated stratigraphic architectures in the pre- and syn-spreading periods of the SCS; (3) depositional infilling in the post-spreading period of the SCS.

The genetic relationship between the deep structure of lithosphere and the stratigraphic pattern has been widely analyzed for this passive margin. Lei et al. (2019) provide seismic descriptions of the Cenozoic structure from a longoffset, crustal scale reflection seismic section in the northern

Xinong Xie

xnxie@cug.edu.cn

1 Faculty of Marine Science and Technology, China University of Geosciences, 388 Lumo Street, Hongshan District, Wuhan 430074, China

2 State Key Laboratory of Marine Geology, Tongji University, Shanghai, China margin of the SCS, which presents an interesting case study to link the rift architecture in the crustal surface with the occurrence and formation of the so called high-velocity layers (HVL). The authors highlights importance of the detachment faulting and associated magma accretion in the deepwater region during the evolution of the passive margin.

Four papers cover tectonic activities and associated stratigraphic architectures during the pre- and syn-spreading periods of the SCS. Among them, two papers focus on the northern margin of the SCS, and the other two on the southern SCS. Huang et al. (2018) examine the onset of Asian epi-continental marginal sea by the integration of both paleontology and sedimentology evidence from the Eocene sequences exposed on Taiwan Island. This research provides new constraints for evolution in the eastern margin of the SCS. Xie et al. (2019) presents the exciting results on the lithosphere break-up process and stratigraphic architectures of the Pearl River Mouth basin in the northern SCS. Their paper describes the distinct stratigraphic framework in the proximal and distal zones of a passive margin during the lithospheric breakup process, and explores the relationship between deep crustal structures and breakup unconformities. Tong et al. (2019) provides a significant insight into tectonic evolution around the southern margin of the SCS based on seismic profiles interpretation. This work contributes to paleo-tectonic reconstruction of the SCS. Peng et al. (2018) presents some newly released industrial seismic data from the SW basin and Dangerous Grounds. Based on stratigraphic and structural analysis, they found distinct segments in the structural architecture of the syn-rift units and the ages of rift-drift transition, showing an obvious change from the proximal to the distal zones. Three domains, the Reed Bank-Palawan Rift domain, the Dangerous Grounds Central Detachment domain and Nam Con Son Exhumation domain, reflect: 1) the propagation of the margin rifting developed initially by high angle faults, and their associated grabens, 2) the large half-grabens controlled by listric faults and detachments and 3) rotating fault blocks in the 
hyper-extended upper crust associated with missing lower crust or even exhumed mantle, which reveal a migration and stepwise rifting process in the south margin of the SCS.

The depositional filling in the post-spreading period of the SCS are characterized by the three aspects. One is the strong volcanic activity in the oceanic basin and even in the continental marginal basins after the cessation of the seafloor spreading of the SCS. Jiang et al. (2018) provides an age sequence on post-spreading volcanism in the SCS using rocks obtained from IODP cores. The authors ascribe the different scales and peak episodes of post-spreading magmatism in different tectonic settings. Secondly, large-scale significant progradational clinoforms prevail in the northern, western and southern margins of the SCS, especially since the Late Miocene. Xu et al. (2019) presents a case study on a progradational clinoform of the West Luconia Deltas in the Zengmu Basin. The paper discusses the evolution of gravity instabilities and their relationship with the progradation of deltas and diapirisms in the gravity-driven system. Thirdly, there are several deepwater canyons that developed during the post-spreading stage. For example, there are three deepwater canyons with a length greater than $200 \mathrm{~km}$ in the northern margin of the SCS: the Central Canyon in the northwest margin, the Pearl River Estuary canyon in the northern margin and the Penghu canyon in the northeast margin, respectively. Cui et al. (2019) presents an case study on the Central canyon in northwest SCS, in which a combination of detrital zircon $\mathrm{U}-\mathrm{Pb}$ dating and geochemistry analysis for the Central Canyon is used for the provenance reconstruction.

This special issue is an important part of the research results of a key research program of the "South China Sea Deep". This study is expected to further deepen our understanding of the evolution of sedimentary patterns on the continental margins of the SCS. It provides a comparative example for the study of tectonics and depositional filling of marginal seas across the world.

Acknowledgements We wish to thank the reviewers who have contributed helpful and constructive comment for, all authors and co-authors in this issue. Those works were supported by the National Scientific Foundation of China (No. 91528301).

\section{References}

Cui Y, Shao L, Qiao P, Pei J, Zhang D, Tran H (2019) Upper miocene-pliocene provenance evolution of the Central Canyon in northwestern South China Sea. Mar Geophys Res. https://doi. org/10.1007/s11001-018-9359-2. (in this issue)

Huang CY, Shao L, Wang MH, Xue WG, Qiao PJ, Cui YC, Hou YL (2018) Benthic foraminiferal fauna and sediment provenance of Eocene syn-rift sequences in Taiwan: implication for onset of Asian epi-continental marginal seas off China coast. Mar Geophys Res. https://doi.org/10.1007/s11001-018-9366-3. (in this issue)

Jiang T, Gao HF, He JK, Tian DM (2018) Post-spreading volcanism in the central South China Sea: insights from zircon $\mathrm{U}-\mathrm{Pb}$ dating on volcaniclastic breccia and seismic features. Mar Geophys Res. https://doi.org/10.1007/s11001-018-9368-1. (in this issue)

Lei C, Ren J, Pang X (2019) Rift structures and its related unconformities on and adjacent the Dongsha Rise: insights into the nature of the high-velocity layer in the northern South China Sea. Mar Geophys Res. https://doi.org/10.1007/s11001-019-09381-x. (in this issue)

Peng X, Shen C, Mei L, Zhao Z, Xie X (2018) Rift-drift transition in the Dangerous Grounds, South China Sea. Mar Geophys Res. https://doi.org/10.1007/s11001-018-9353-8. (in this issue)

Tong D, Ren J, Liao Y, Yao Y, Zhao Y (2019) Cenozoic tectonic events and their implications for constraining the structure and stratigraphic styles from rifting to collision at the southeastern margin of the South China Sea. Mar Geophys Res. https://doi. org/10.1007/s11001-018-09376-0. (in this issue)

Xie X, Ren J, Pang X, Lei C, Chen H (2019) Stratigraphic architectures and associated unconformities of Pearl River Mouth basin during rifting and lithospheric breakup of the South China Sea. Mar Geophys Res. https://doi.org/10.1007/s11001-019-09378-6. (in this issue)

Xu J, Ren J, Luo P (2019) The evolution of a gravity-driven system accompanied by diapirism under the control of the prograding West Luconia Deltas in the Kangxi depression, Southern South China Sea. Mar Geophys Res. https://doi.org/10.1007/s1100 1-019-09384-8. (in this issue)

Publisher's Note Springer Nature remains neutral with regard to jurisdictional claims in published maps and institutional affiliations. 